\title{
Comparison and Analysis of Lightweight Steel Structure Residential Housing
}

\author{
Xiaolu Li, Jiahui Wang, XiangPeng Meng, Jingyuan Wang \\ College of Urban and Rural Construction \\ Hebei Agricultural University \\ Baoding, China \\ e-mail: lixiaoludream@sina.cn, chjtw@hebau.edu.cn
}

\begin{abstract}
The lightweight steel structure residential building has properties of the green, energy-saving, environmental protection and etc. In the past few decades, there have been a growing interest in the use of cold-formed steel structure in all aspects of building construction, and in many developed countries, there have been significant developments about cold-formed structural building. However, in some developing countries, lightweight steel structure residential building just started. In this paper, we introduce some properties of lightweight steel structure residential buildings and the current research situation. On the basis of them, we analyze and study lightweight steel structure residential buildings in North America, Japan and Europe in detail, and give their some features. Then according to China particular conditions, development status and properties are introduced about lightweight steel structure residential building, including some traditional housing concept, and intensive steel residential building. Based on above investigations, some suggestions and countermeasures are given. It is believed that it is significant and helpful for promoting China housing industrialization.
\end{abstract}

Keywords- lightweight steel structure; component; residential building ; cold-formed structure; low multilayer

\section{INTRODUCTION}

With the development of the construction industry, changes in building systems and construction materials has become the current trend in the development of residential buildings. In recent years, due to the continuous improvement of people's living standards, they have higher requirements for the housing, stability, etc., especially for low-rise residential, there is an urgent need for research, development and promotion of beautiful styling, excellent structural performance, use of convenience, construction speed, economy and reasonable residential building system to replace the existing architecture.

Light steel structure housing is based on economy steel members as the load-bearing skeleton, using pressure plate or sheet material as a lightweight wall envelope, and high-strength bolts and other connectors and sealing materials will be load-bearing components, building envelope components such as on-site assembled prefabricated residential building class [1]. It can be seen that the main building material for the light steel structure housing is the galvanized lightweight steel keel as major structural components, the most important advantage using this material is that you can guarantee a good residential properties, but can also ensure that the constructed house with a dead weight light weight, high degree of prefabrication, construction speed, small labor intensity of the advantages [2,3]. Light steel structure residential housing compared with the previous tradition has the following advantages: a stable structure; low cost; span light steel structure villa house space than concrete buildings span; galvanized steel corrosion resistance of its use can be excellent, durable, use life is long. However, light steel housing in China is still in the development stage. There are still some serious problems in residential design process to need further study. To this end, this paper analyzes and compares light steel residential, and introduces the characteristics of foreign and domestic light steel housing. And we give some reasonable suggestions.

The paper is organized as follows. Section 2 describes the characteristics of light steel housing abroad. Section 3 describes the current development of China light steel and steel residential housing characteristics. Conclusion is given in final section.

\section{LIGHT STEEL HOUSING ABROAD}

\section{A. North American Light Steel Housing}

North American light steel housing is from a wooden structure with lightweight wooden structure characteristics. In the North American residential market, they account for $20 \%$ of the share [4]. Housing skeleton is mainly coldformed C-shaped steel keel system and usually one to two-story villa housing built in the high incidence of earthquakes in California and other regions. Some of light steel housings in North American are given in Fig .1.
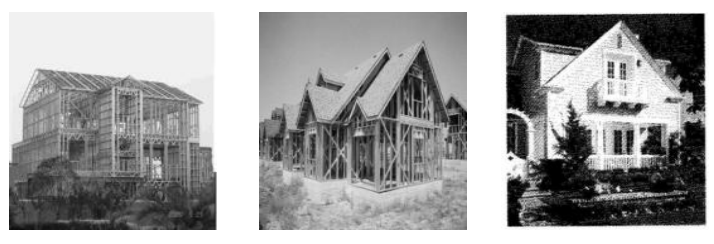

Figure 1. Light steel housing in North American

In reality, this lightweight steel system has been very mature in North America. Now, they can build multi- 
storey residential building using this technique from five layers to six layers. It is worth of mentioning that the most active part of research in the US is on cold-formed steel structures. The reasons for this are the expanding of supporting industry, especially in the area of individual family dwellings and rise of the cost of wood. Thus, steel framed houses become more and more economical[5]. Pekoz [6] states that in the USA, about 500 homes were built in light gauge steel in 1992. This number rose to 15 000 in 1993 and 75000 in 1994. A further five-fold increase is estimated by 2002 . The primary framing elements for this form of construction are cold-formed steel wall studs and floor joists. Light gauge steel roof trusses or rafters are also used. At present, the United States have produced such a keel system for a hundred companies. Among them, famous company is the Dietrich company, which is the subsidiary of Worthington Industrial Company. They developed DBS system for building multi-storey light steel housing [4]. Using DBS technology system can be built multi-storey residential light steel structure. Its wall uses C-channel gypsum board on both sides and floor uses C-type light steel keel laying $20 \mathrm{~mm}$ thick fiber cement board, and are filled with glass wool insulation spacer, which plays sound effect. In the United States, cold-formed C-sections are commonly used as roof truss members[7]. In reality, early purlin shapes were simple lipped channels and Zed sections. The simple channel has evolved into Multibeam Marks I, II and III, the latter having a compound lip. A similar trend can be seen in the evolution of the Zed into the Zeta and Ultrazed shapes, as shown in Fig .2[6]. Cold-formed members can be produced in a wide variety of section profiles. The most commonly used components are the $\mathrm{C}$ channels and the $\mathrm{Z}$ sections shown in Fig .3[10]. This lightweight steel in North America exists in stand-alone or townhouse because of its poor sound insulation. To resist lateral wind loads and seismic action, the U.S. multi-light steel structure residential system has two kinds of methods: the use of light steel shear walls or cross steel frame support structure. Light steel shear walls are generally arranged in the household, using $0.5 \mathrm{~mm}$ galvanized sheet steel Mongolia in gypsum board, and then fixed on the light steel wall studs, similar to the formation of shear stress in skin structure between each layer there is a special component of the shear wall to connect the upper and lower floors to effectively transfer horizontal shear and tension due to the horizontal force acting on the wall studs produced. In the earthquake zone, in order to ensure structural safety, the support of the Cape with a cross is used as a lateral force resisting steel frame structure to form a hybrid architecture system, where light steel withstands the vertical loads and ordinary steel withstands horizontal loads. To ensure wall insulation effect, besides the wall studs filled with glass fiber, a layer of insulation on the outside wall material is pasted. Using this method effectively cuts off thermal bridge from the wall studs to the wall panels. The floor joists are filled with glass fiber to reduce heat transfer through the floor. Glass fiber is filled between the wall studs located on interior wall to reduce household heat transfer between the walls.

\section{B. Steel Sheet Residential Construction In Japan}

As Japan is an earthquake-prone zone and lightweight steel has good characteristics of seismic effects, lightweight steel is locally popular. In accordance with their own unique characteristics, Japan build light steel housing, namely Sheet Steel housing, as shown in Fig .4 below $[8,9]$. This structure uses new construction process, i.e. uses a non-welded galvanized cold-formed steel combination, also known as Steel $2 \times 4$, which is a residential craft with a plate rib structure. The structure is an architectural form from former North American. Wall panels and floor is built by using wood based on box. However, in sheet steel housing, sheet material is replaced with steel, whose thickness is $1.0 \mathrm{~mm}$ or so. In two sides, lightweight gypsum board is affixed. By this method, overall structure's performance such as stable, durability, thermal insulation, sound insulation properties and etc., is achieved.

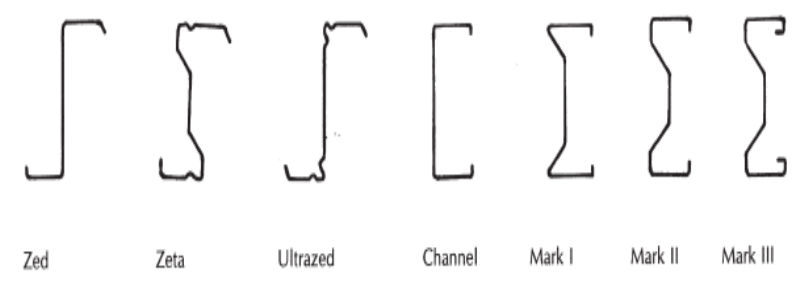

Figure 2. Evolution of cold-formed purlin sections.
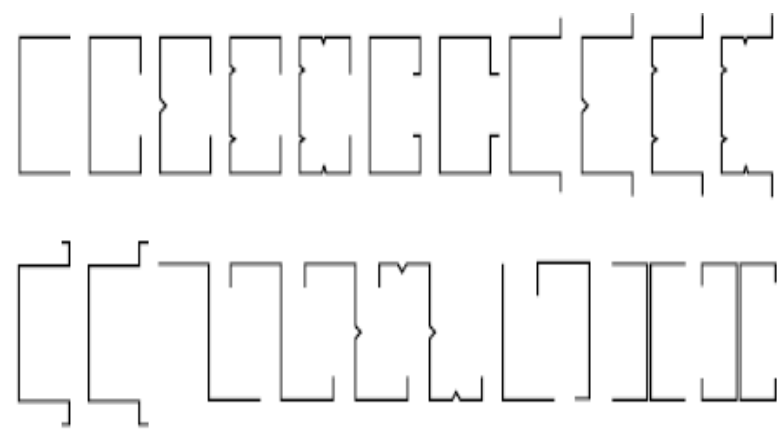

Figure 3. Cold-formed sections used in construction application
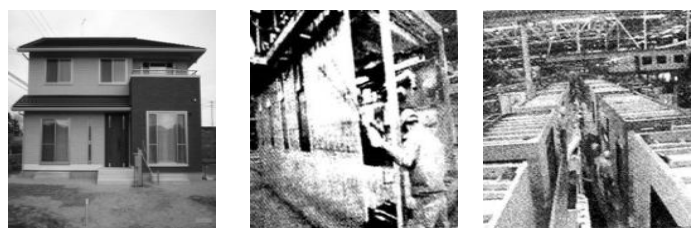

Figure 4. Steel sheet residential construction in Japan

In reality, this steel sheet structure building is a construction which combines the strengths and advantages of steel and plate ribs process. The building entities' experiments demonstrated that it has excellent performance characteristics such as the seismic of resistance, wind load performance and anti-snow load performance. In 2003, the Japanese's construction material is changed from wood to thin steel keel. Aiming at the architectural features, building codes in Japan, special instructions when building set automatic fire extinguishing and automatic exhaust system, internal decoration 
materials made from time to fire protection requirements [8].

\section{Energy-Efficient Residential Building In Europe}

Germany began to implement the new building energy specification from 2002 [9]. Its core is the quantification of energy consumption. The energy consumption of each house is required to provide building energy calculations to the competent authorities as necessary documents houses. It has a major impact on the country's residential development and building materials market. In energysaving residential buildings, Sweden uses renewable energy as far as possible, including wind energy, solar energy, geothermal and other energy sources, and integrates these technologies. In short, European countries more focus on the study of energy efficiency and green building. Now, cold-formed steel components can be rapidly and accurately assembled into complete structural units for delivery to the site. In the UK, most out of town hotels and motels are now built in this way. The UK construction industry currently uses over 300,000 ton of cold-formed steel products annually, and this consumption rate is growing steadily[10].

\section{LIGHT STEEL HOUSING IN CHINA}

\section{A. The Development Status Of Light Steel Housing}

For a long time, housing construction is mostly dominated by concrete in China. It is no longer suitable for the theme of today's green buildings as it needs large materials and long construction period. As China has been the largest producer of steel in the world since 1996, as shown in Fig .5, the state government started to encourage the use of steel in civil engineering industry. With construction steel processing industry growing up day by day, steel structure construction in China has stepped into a high-speed developing period [11].

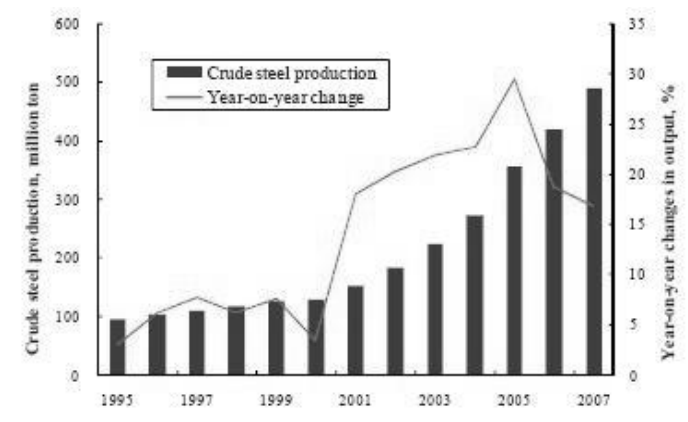

Figure 5. Crude steel production in China

Since light steel components easily are produced by factory with high degree of mechanization, high degree of commercialization, and fast construction speed on site. And it does not affect nearby residents and the construction of civilization favor is very high. Light steel is an environmentally friendly, sustainable development product and its comprehensive economic indicators are not higher than the reinforced concrete structure. Therefore, light weight, good seismic performance of light steel building must become the mainstream in the construction industry. Now, building is experiencing the conversion from concrete structure to ordinary steel building and from ordinary steel building to light steel structure. Development of steel residential building does not pursuit advanced technology and special tools and should focus on mature, integrated and practical housing technology like the European countries. In the process of integration, key is the detailed structure and mutual convergence.

\section{B. The Characteristics Of Light Steel Housing}

Light steel is a new concept at first. With the improvement of people's living standards, it gradually goes into people's lives. In China's some major cities such as Beijing, Shanghai and other places, light steel structure residential building has been established by introducing technology from North America and Japan into China. At present, most of the light steel housing in China belongs to light energy-saving housing construction which uses steel frame structure, light wall, light floor, light roof construction system. Using ordinary H-beam welding steel, small section of hot-rolled H-beam or straight section steel and combining anti-profiled wall lateral force factor, multilayer structure can be built. And it is consistent with our current specification system and meets seismic requirements [9]. In 2011, China issued and implemented the "low-level cold-formed steel building construction technical regulations", which combines the cold-formed steel keel system in North America and promote this keel system. In the process of designing using C-channel coldformed steel and U-shaped steel, load-bearing walls consist of column, top and bottom guide beam guide beam, support, brace and struts, wall panels and other structural components [12], as shown in Fig .6 below. Despite the provisions of the relevant specifications, but this structure is still not large popularity. Although light steel structure has some advantages, for example, light weight, excellent seismic performance, short construction period, structural stability and other characteristics, but it also has some problems to be further addressed, such as large noise and poor refractory. This short construction period of the building is now not be recognized by the people and its safety and reliability is not verified.
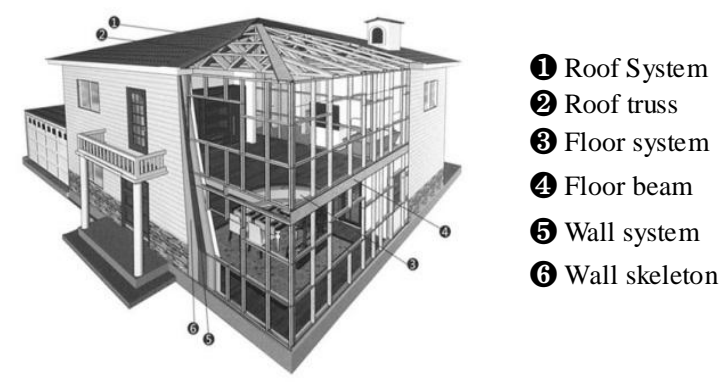

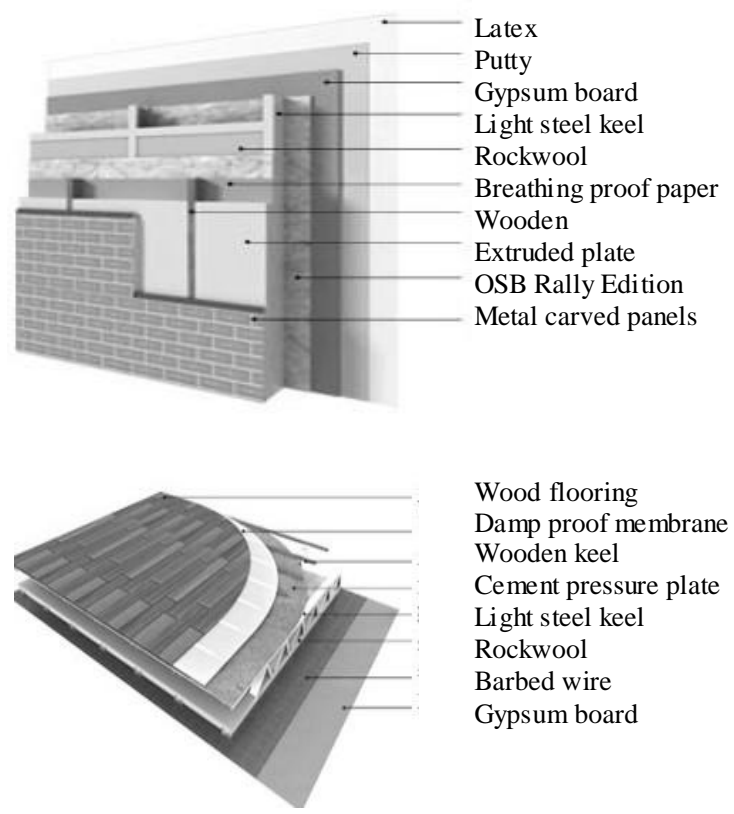

Wood flooring

Damp proof membrane Wooden keel

Cement pressure plate Light steel keel

Rockwool

Barbed wire

Gypsum board

Figure 6. Light steel housing composition and some components

But this light steel building is the development trend of China architecture and needs more researchers study its safety, reliability and durability. In a word, China is at the beginning of lightweight residential buildings of steel structure and has a long way to go. Compared with the developed countries, there are a lot of questions and China still lacks behind a lot. It needs to be improved and perfected continuously [13].

\section{Recommendations And Strategies}

As lightweight steel structure residential housing is of good performance, light weight, high degree of factory, construction speed, low labor intensity, etc., it gradually developed in the United States and Europe in the last three decades and has created a set of very mature technology. Now, many domestic and foreign enterprises invariably want to migrate light steel structure residential technology to China, but they do not make sense. The reasons are as follows:

1) There isn't systematic lightweight steel specification Although the "cold-formed steel structure technical regulations" was promulgated in 2011, but it is hardly consider making major load-bearing components with steel thickness $2 \mathrm{~mm}$ or less. For system of plating zinc metal frame bearing with the extensive use of wall thickness 0.8 $1.6 \mathrm{~mm}$ abroad, neither theoretical analysis nor relevant experimental data of the structure exist, which makes light steel structural design very difficult in China.

2) Society as a whole requires a process to accept this new housing system. People are still very strange for such a structure and they still poorly understand its security, stability, comfort and etc.

3) Project cost is high. As the technology is still in its infancy, the lack of skilled workers and the need of light steel components introduced from abroad incur the higher housing prices. To solve the above problems, the following recommendations and strategies:

1) To improve lightweight steel specification, constructing a number of pilot projects makes this aspect of technology gaps. Large enterprises with doing this research in this area should be supported.

2) On the basic of construction of pilot projects and obtained experience, one should seize the opportunity to prepare the corresponding light steel structure house technical standards and codes.

3) Once the technical standard is promulgated, the technology system should be incorporated into professional schools as teaching content.

4) Some of the successful experiences of foreign countries are absorbed. Aiming at specific situation, scientific research is conducted. States should make some policies to support the research of this technique so that light steel structure is popularized step by step. By means of this method, it hopes that more people will recognize this structure.

\section{CONCLUSION}

In short, low-light steel multi-storey residential building in China has good prospects for development with less materials, small pollution, short construction period and in line with the development trend of domestic architecture. It will become a new situation of China's residential buildings. With promulgation of steel residential building technical guidelines and specifications, low light steel residential multi-storey must also further developed. By absorbing and improving technology of light steel structure system abroad, increasing production capacity and capacity development of steel technology, I believe light steel structure will be widely used and developed in China.

\section{ACKNOWLEDGMENT}

This work is supported by Undergraduate Innovation Project of Hebei Agricultural University under Grant 201310086018

\section{REFERENCES}

[1] Y.Q. Wang, Y.J.Shi,H.Chen, et al., "Contemporary lightweight steel structure and its application in China," Journal of building structures, vol. 23, no. 1, pp.1-7, 2002.

[2] K. Yi, "Development and application prospect of light weight steel structure housing," Shanxi architecture,vol. 37, no. 14, pp.3031,2011 .

[3] B. Liu, X. L. Chen, "Explore the design features low multilayer light steel residential and implementation," China Construction Metal Structure, no. 7,2013.

[4] Z. Y. Tong, N. L. Lou, "U.S. residential multi-storey light steel structure," Residential Technology, no. 11, 2004.

[5] T. V. Galambos, "Recent research and design developments in steel and composite steel-concrete structures in USA," Journal of Constructional Steel Research,vol. 55, pp.289-303,2000.

[6] J. M. Davies, "Recent research advances in cold-formed steel Structures," Journal of Constructional Steel Research,vol. 55, pp. 267-288, 2000.

[7] R. A. LaBoube, W. W. Yu, "Recent research and developments in cold formed steel framing," Thin-Walled Structures, vol. 32, pp.1939, 1998.

[8] H. Shinichiro, "Sheet Steel Building in Japan in the development and popularization," Housing industry, no. 11, in 2004.

[9] M. G. Wang, D. W. Chu. Lightweight steel housing. China Building Industry Press, Beijing, 2011.

[10] E. M. A. EI-Kassas, R. I. Mackie, A. I. EI-Sheikh, "Using neural networks in cold-formed steel design," Computers and structures, vol. 79, pp.1687-1696,2001. 
[11] X. Cheng, X. Z. Zhao,Y. Y. Chen, "Overall investigation of affordable residential housing in China," Proc. International Conference on Electric Technology and Civil Engineering (ICETCE) ,2011, pp.539-543.

[12] Technical specification for low-rise cold-formed thin-walled steel buildings, China Building Industry Press, 2011, Beijing.
[13] H. L. Zhao,B. Y. Pan, D. Y. Gu, "Current situation and countermeasures of lightweight steel structure residential buildingindustrialization in Henan," World Automation Congress (WAC), pp. 1-4,2012. 